\title{
Age and smoking as risk factors for malignancy in patients with peripheral solitary pulmonary nodules
}

\author{
Georgi Prisadov' ${ }^{1}$ Angel Uchikov², Kathrin Welker ${ }^{1}$, Herbert Wallimann ${ }^{1}$, Emeka Kesieme ${ }^{1}$ \\ 1. Clinic of Thoracic Surgery, Academic Teaching Hospital Bremen-East, Bremen, Germany. 2. Clinic of Thoracoabdominal \\ Surgery, Medical University, Plovdiv, Bulgaria \\ Correspondence: Georgi Prisadov. Address: Clinic of Thoracic Surgery, Academic Teaching Hospital Bremen-East, \\ Bremen, Germany. E-mail: prisadov@t-online.de
}

Received: January 19, 2013

Accepted: February 15, 2013

Online Published: February 27, 2013

DOI : $10.5430 /$ jst.v3n2p63

URL: http://dx.doi.org/10.5430/jst.v3n2p63

\section{Abstract}

Objectives: The objectives of the present study were to find if there is any correlation between patients' age, tobacco smoking and tumor malignancy and determine if these variables should be considered risk factors for malignancy.

Patients and methods: The study included 145 patients with peripheral pulmonary tumors of less than $3 \mathrm{~cm}$ in diameter that received a video-assisted thoracoscopic (VATS) resection for tissue diagnosis between 1998 and 2009.

Results: The mean patients' age was 62.60 years. The youngest patient was 17 years old, and the oldest - 82 years old. The study sample included 61 women and 84 men; the men were statistically significantly more than the women $(57.3 \%$ and $42.07 \%$, respectively) $(t=2.74, P<0.01)$. Of the 145 patients we operated, $69(47.59 \%)$ had benign tumors, and $76(52.41 \%)$ - malignant; of the latter, $41(53.95 \%)$ had a primary lung carcinoma and 35 (46.05\%) - lung metastases. All lesions had a diameter that was in the range of $0.30 \mathrm{~cm}$ to $3 \mathrm{~cm}$ (mean $1.41 \mathrm{~cm})$. Malignant tumors were found to have their peak in the age between 61 and 70 years followed by tumors in patients over 70 years $\left(\chi^{2}=14.06, \mathrm{df}=6, P=0.029\right)$. Primary lung cancer found in smokers was $44.87 \%$, which is about 2.5 times higher than primary lung cancer found in non-smokers (19.35\%).

Conclusion: The results we had in this study suggest that age over 60 and tobacco smoking is important risk factors for malignancy.

\section{Key words}

Solitary pulmonary nodule, Age, Smoking, Malignancy

\section{I ntroduction}

A solitary pulmonary nodule is a single mass lesion of unclear etiology which is seen on X-rays as a well-marginated rounded opacity less than or equal to $3 \mathrm{~cm}$ in diameter and surrounded by normal lung parenchyma and unassociated with atelectasis or lymphadenopathy ${ }^{[1,2]}$. More than 80 nosological entities have been known to present radiologically as peripheral rounded opacities. They range from benign lesions to primary bronchial carcinomas or pulmonary metastases ${ }^{[1-3]}$. 
The prevalence of the newly found solitary pulmonary nodules has recently been found to increase ${ }^{[2,4]}$.

According to literature estimates, $30 \%$ to $68 \%$ of these lesions are malignant ${ }^{[2]}$. Bronchial carcinoma is the most frequent of these lesions and the only therapeutic modality known currently to be efficient in treating these tumours is immediate surgical resection. It is therefore important that a prompt and definitive tissue diagnosis be made ${ }^{[2,5,6]}$.

With the advent of such imaging techniques as HR-CT and PET in the last 20 years the diagnostic accuracy in this respect has been considerably improved without however solving definitively the problem with the histological identification of solitary pulmonary nodules which still present a serious diagnostic and therapeutic challenge ${ }^{[7-10]}$. The moment they are detected clinicians are faced with the dilemma of whether they should simply wait and observe or operate the tumours immediately. This problem is often hard to solve depending as it does on many other factors ${ }^{[11,12]}$.

We therefore sought to find if there is any correlation between age of patients, tobacco smoking and tumour malignancy.

\section{Material and methods}

The present study included 145 patients (aged 17 through 82 years) who were diagnosed with solitary pulmonary nodules of unknown histological character; the nodules measured $3 \mathrm{~cm}$ in diameter and less, and were located in the lateral third of the lung and in the interlobar fissures. All patients underwent video-assisted thoracoscopic surgery (VATS), 5 of the patients bilaterally; a total of 150 surgical procedures were performed in the following clinics:

- The Clinic of Thoracoabdominal Surgery in Plovdiv Medical University, Bulgaria - 21 patients operated between 01.01.1998 and 30.06.2002.

- The Clinic of Visceral, Vascular and Thoracic Surgery in the University Hospital of Aschersleben, Germany - 57 patients operated in the period from 01.06.2005 to 31.07.2009.

- The Clinic of Thoracic Surgery, University Hospital, Bremen-East, Germany - 67 patients between 01.05.2008 and 31.07.2009.

All patients were administered a standardised preoperative diagnostic procedure which included conventional X-ray study, lung CT, and bronchoscopy with cytological examination of bronchial secretion. Despite of all these investigations no definitive diagnosis could be made based on that. A transthoracic biopsy in operable patients for the purpose of presurgical diagnostics was considered redundant.

All patients received at first an atypical lung resection in which we removed the tumor and made an intraoperative cryosection histologic test. In case the histology study finds malignant tissue the surgical procedure is adjusted accordingly as required by the oncological criteria for management of neoplasms.

The statistical analysis used parametric, nonparametric and graphic methods to present the results and calculate them using SPSS v. v17.

\section{Results}

The youngest patient was 17 years old, the oldest - 82 years. The mean age of the patients was 62.60 years. The study sample included 61 women and $84 \mathrm{men}$; the men were statistically significantly more than the women $(57.3 \%$ and $42.07 \%$, respectively) $(t=2.74, P<0.01)$. There was no significant difference between men and women in their age distribution $\left(\chi^{2}=3.68, \mathrm{df}=7, P>0.05\right)$.

Seventy patients (48.28\%) had a history of malignancy; the remaining 75 patients $(51.72 \%)$ had no previous history of tumors. We found no statistically significant difference between these two groups $(t=0.59, P>0.05)$. 
Figure 1. Correlation between age of patients and histological character of tumor

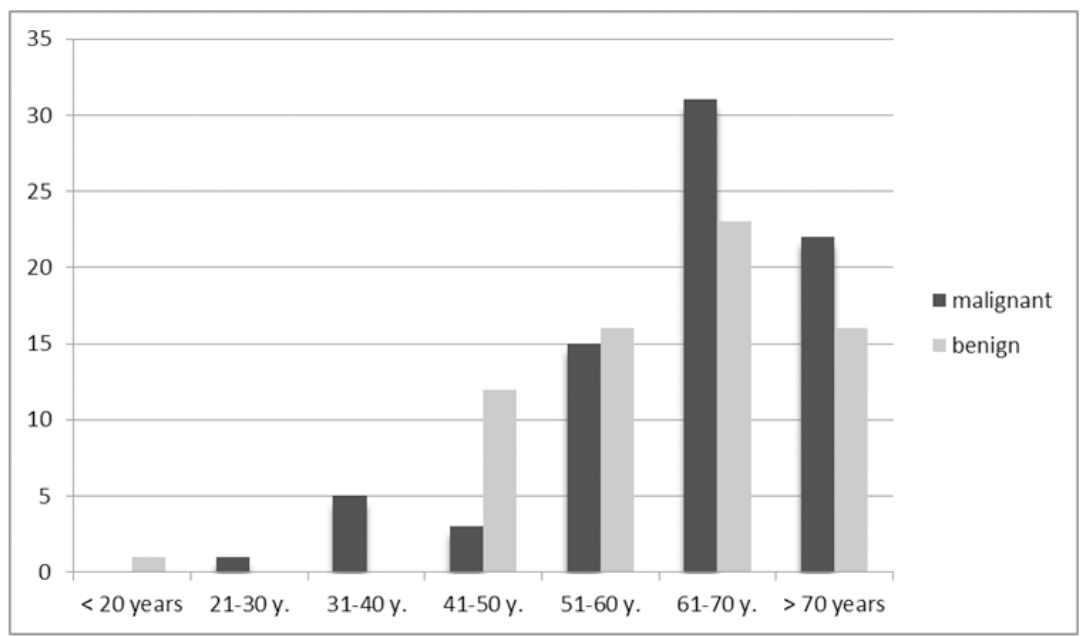

Out of the 145 patients we operated, 69 (47.59\%) were found to have benign tumors and $76(52.41 \%)$ had malignant tumors. Forty-one patients $(53.95 \%)$ with malignant tumors had a primary lung carcinoma and $35(46.05 \%)-$ lung metastases.

The diameter of the nodules varied between 0.30 and $3 \mathrm{~cm}$ (mean diameter $1.41 \mathrm{~cm}$ ).

We sought to find if there is any difference in the frequency of malignant tumors in different ages. For this purpose we divided the patients into 7 age groups: a group with patients under 20, 5 groups at 10-year intervals, and a group of patients over 70. Figure 1 shows the distribution of patients by age and malignancy of tumor.

Malignant tumors were found to increase considerably with age; their peak was in people 61-70 years of age followed by patients over 70 years $\left(\chi^{2}=14.06, \mathrm{df}=6, P=0.029\right)$. We found no malignant tumors in the 20 -year-olds. One patient in the group of 21-30-year olds had metastases from sarcoma, and 5 patients of the 31-40-year olds had malignant tumors: one bronchial carcinoma and four patients with metastases.

Figure 2. Correlation between smoking and tumors histology

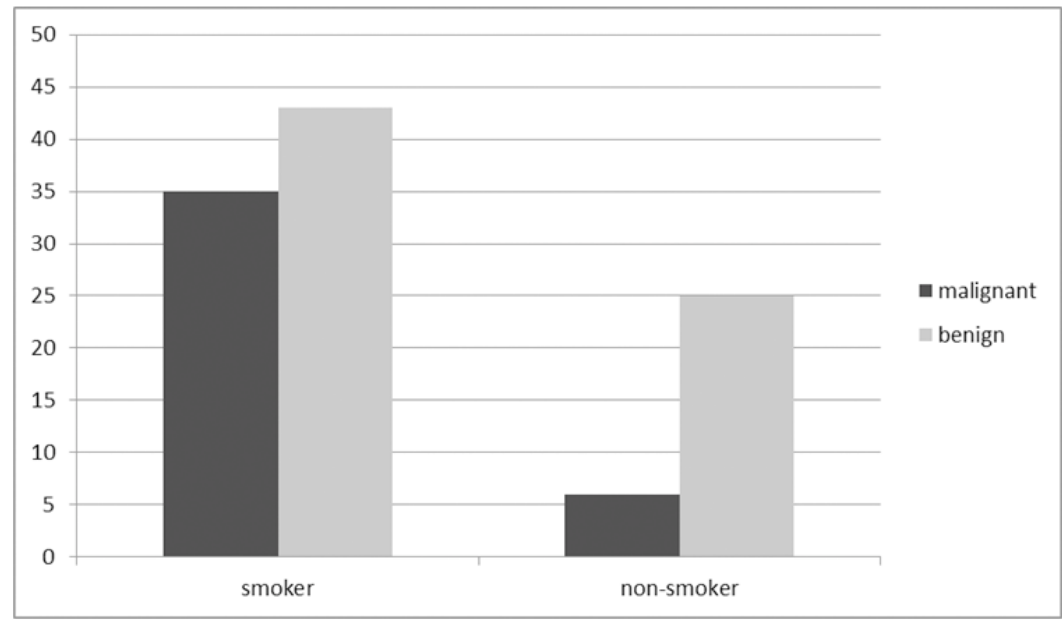


We sought to find if there was any correlation between tobacco smoking and the tissue diagnosis. All patients with lung metastases of extra pulmonary primary tumors (35) were excluded from the study out from the number of all 145 operated patients. Insufficient data about one patient reduced the study sample to 109 patients. Seventy-eight of them (71.55\%) was smokers and 35 of these (44.87\%) had primary lung cancer. The non-smokers group -31 patients $(28.45 \%)$ had only 6 patients $(19.35 \%)$ with primary lung cancer. The distribution of patients by smoking history and tumor histological diagnosis is shown in Figure 2.

We performed multiple factor regression analysis with the histological characteristic of the tumor as a variable coded as a binary parameter (zero for benign tumors and 1 for malignant tumors). As a dependent variable we considered:

- Smoking was coded as binary parameters (zero for non-smokers, and 1 for smokers; non-smokers were used as reference)

- Patient's age was analyzed as a continuous variable.

We found that with increasing age increases the risk for malignancy. In smokers it is 4 times higher than in non-smokers. Smoking is a statistically significant risk factor for malignancy. (Table 1)

Table 1. Multiple factor regression analysis

\begin{tabular}{llll}
\hline & Relative risk Exp(B) & 95\% CI & P \\
\hline Smoking & & & \\
No ${ }^{*}$ & 1 & & \\
Yes & 4.28 & $1.48 ; 12.33$ & 0.007 \\
Const & 0.22 & & 0.002 \\
Age & 1.017 & $0.988 ; 1.048$ & 0.252 \\
Const & 0.388 & & 0.318 \\
\hline
\end{tabular}

*referent category

\section{Discussion}

The prevalence of malignant cancer in patients with solitary nodules, as given in literature, ranges from 30 to $68 \%{ }^{[2]}$. Bergmann et al. have found that benign tumors in such cases are as frequent as $60 \%{ }^{[2]}$.

In 2008 Varoli $\mathrm{F}$ et al. reported of 276 solitary lung nodules they removed and found 138 of them (50\%) to be malignant ${ }^{[13]}$.

Our results are consistent with the findings in these studies - we found $54.55 \%$ malignant nodules and $45.45 \%$ benign tumors.

The difference in the results reported in literature can probably be accounted for by the simple reason of preselecting the study patients - some of these studies did not include patients with history of cancer.

In 2008 Dürkes P reported results similar to those we found ${ }^{[14]}$. The mean age of the patients with solitary lung nodules they operated was 60.4 years. The highest frequency of malignant lesions in their study was found just like in our study in the group aged between 61 and 70 years $(68 \%)$.

Schmidt $\mathrm{W}$ found that the age distribution of solitary lung nodules is similar to the age distribution of non-small cell bronchial carcinoma the most affected group in their study being that aged $61-70$ years ${ }^{[15]}$. 
According to Cardillo et al. the age of patients is a significant risk factor for malignancy. In their study they reported an increase in the prevalence of malignant tumors with age ${ }^{[16]}$.

Also, Dürkes P reports of a relatively high incidence of malignant lesions in young patients: in $5(42 \%)$ of their patients under 40 and in 8 (32\%) of patients between 41 and 50 years the tumors were malignant. On the basis of these results they concluded that it was impossible to produce a statistically significant prognosis for the malignant character of these tumors and therefore the lesions should be first subjected to tissue diagnosis ${ }^{[14]}$.

For precisely the same reasons Cardillo et al recommended a histologic diagnosis using VATS ${ }^{[16]}$.

In the present study we found no malignant tumors in the patients under 20 years of age, sarcoma metastases in 1 patient $(1.3 \%)$ in the group $21-30$ years, while in the $31-40$-year-olds there were 5 patients $(6.5 \%)$ with malignant lesions (a primary lung carcinoma and 4 metastases).

These data suggest that the patients' age is a significant risk factor for malignancy, although young age does not automatically exclude presence of malignant tumors.

There has been done much research which demonstrates that tobacco smoking can be a primary risk factor for the occurrence of lung carcinoma ${ }^{[17,18]}$.

Dürkes P reports that the relative percentage of primary lung carcinoma in smokers is about twice as great as the relative percentages of lung carcinoma in non-smokers. But the relative percentage of metastases and benign lesions is high in non-smokers. For this reasons they recommend that every newly found solitary lung nodules, regardless of the smoking history of the patient, should be subjected to tissue diagnosis ${ }^{[14]}$.

We are of completely the same opinion: we think that smoking is a statistically significant risk factor for malignancy, although no smoking history does not preclude development of malignant lesions.

On the basis of the results reported herein we can make the following conclusions:

Patients' age and tobacco smoking are significant risk factors for malignancy. Therefore these should always be taken into consideration in determining the individual risk profile of a patient and the respective diagnostic and therapeutic approach to this patient.

\section{References}

[1] Tan BB, Flaherty KR, Kazerooni EA, Iannettoni MD. The solitary pulmonary nodule. Chest. 2003; 123: 89-96. http://dx.doi.org/10.1378/chest.123.1_suppl.89S

[2] Bergmann T, Bölükbas S, Beqiri S, Trainer S, Schirren J. Solitary pulmonary nodule. Assessment and therapy. Chirurg. 2007; 78: 687-97. PMid:17634905 http://dx.doi.org/10.1007/s00104-007-1379-4

[3] Ost D, Fein AM, Feinsilver SH. Clinical practice. The solitary pulmonary nodule. Engl J Med. 2003; 348(25): $2535-42$. PMid:12815140 http://dx.doi.org/10.1056/NEJMcp012290

[4] Swensen SJ, Jett JR, Hartman TE, Midthun DE, Sloan JA et al. Lung cancer screening with CT: Mayo clinic experience. Radiology. 2003; 226: 756-61. PMid:12601181 http://dx.doi.org/10.1148/radiol.2263020036

[5] Porrello C, Alifano M, Forti Parri SN, Sanna S, Lacava N et al. Surgical treatment of stage I lung cancer. Results and prognostic factors. J Cardiovasc Surg. 2002; 43: 723-7.

[6] Smythe WR. Treatment of stage I non-small cell lung carcinoma. Chest. 2003; 123: 181-187.

http://dx.doi.org/10.1378/chest.123.1_suppl.181S 
[7] Christensen JA, Nathan MA, Mullan BP, Hartman TE, Swensen SJ et al. Characterization of the solitary pulmonary nodule: 18F-FDG PET versus nodule enhancement CT. Am J Roentgenol. 2006; 187: 1361-7. PMid:17056930 http://dx.doi.org/10.2214/AJR.05.1166

[8] Fletcher JW, Kymes SM, Gould M, Alazraki N, Coleman RE et al. A comparison of the diagnostic accuracy of 18F-FDG PET and CT in the characterization of solitary pulmonary nodules. J Nucl Med. 2008; 49: 179-85. PMid:18199626 http://dx.doi.org/10.2967/jnumed.107.044990

[9] Wormanns D, Diederich S. Characterization of small pulmonary nodules by CT. Eur Radiolog. 2004; 14: 1380-91. PMid:15148623 http://dx.doi.org/10.1007/s00330-004-2335-z

[10] Herder GJ, Golding RP, Hoekstra OS, Comans EF, Teule GJ et al. The performance of 18 F- fluorodeoxyglucose positron emission tomography in small solitary pulmonary nodules. Eur J Nucl Med Mol Imaging. 2004; 31: 1231-6. PMid:15175835 http://dx.doi.org/10.1007/s00259-004-1552-7

[11] Soubani AO. The evaluation and management of the solitary pulmonary nodule. Postgrad Med J. 2008; 84: 459-66. PMid:18940947 http://dx.doi.org/10.1136/pgmj.2007.063545

[12] Breitenbücher A. Der pulmonale rundherd. Schweiz Med Forum. 2005; 5: 80-6. (German)

[13] Vatoli F, Vergani C, Caminiti R, Francese M, Gerosa C et al. Management of solitary pulmonary nodule. Eur J Cardiothorac Surg. 2008; 33: 461-465. PMid:18203611 http://dx.doi.org/10.1016/j.ejcts.2007.12.004

[14] Dürkes P. Der kleine Lungenrundherd, VDM Verlag Dr. Müller, Saarbrücken. 2008; S.12. (German)

[15] Schmidt W. Bronchialkarzinom und andere neoplasien. Manuale Pneumologicum. Kapitel I. 2000; 16: S.1-81. (German)

[16] Cardillo G, Regal M, Sera F, Di Martino M, Carbone L et al. Videothoracoscopic management of the solitary pulmonary nodule: a single institution study on 429 cases. Ann Thorac Surg. 2003; 75: 1607-12. http://dx.doi.org/10.1016/S0003-4975(02)04827-0

[17] Ando M, Wakai K, Seki N, Tamakoshi A, Suzuki K et al. Attributable and absolute risk of lung cancer death by smoking status: findings from the Japan Collaborative Cohort Study. Int J Cancer. 2003; 105(2): 249-54. PMid:12673687 http://dx.doi.org/10.1002/ijc.11043

[18] Lubin JH, Caporaso NE. Cigarette smoking and lung cancer: modeling total exposure and intensity. Cancer Epidemiol Biomarkers Prev. 2006 Mar; 15(3): 517-23. PMid:16537710 http://dx.doi.org/10.1158/1055-9965.EPI-05-0863 